IGUSABDER, 6 (2018): 535-550

\title{
Multiple Skleroz (MS) Hastalığı Öncesi ve Sonrası Beslenme Alışkanlıklarının Karşılaştırılması, Yeterli ve Dengeli Beslenmenin MS Ataklarına Olan Etkisinin İrdelenmesi
}

\author{
Ayşe Huri ÖZKARABULUT* ${ }^{*}$, Hande Nur ONUR ${ }^{* *}$, İpek YAŞAR ${ }^{* * *}$
}

\section{Öz}

Amaç: Bu çalışmada Multiple Skleroz (MS) hastalığı öncesi ve MS hastalığı sonrası beslenme alışkanlıklarının karşılaştırılması, yeterli ve dengeli beslenmenin MS ataklarına olan etkisi incelenmiştir.

Yöntem: Bu çalışma internet üzerinden oluşturulan veri toplama formu doğrultusunda yer gözetmeksizin ulaşılan, MS tanısı almış yaş ortalaması 34,08 77,93 yıl olan 98 hastanın katılımı ile oluşmuştur. Katılımcıların MS öncesi ve sonrası beslenme durumları, genel bilgileri, ağırlık ve boyları, eğitim düzeyleri, çalışma durumları ve fiziksel aktivite düzeyleri değerlendirilmiştir. Veriler değerlendirilirken SPSS programı kullanılmıştır.

Bulgular: Sonuçlara göre atak sıklığını azaltmada probiyotik, prebiyotik, posa, B1 vitamini ve selenyum kaynağı ürünleri tüketiminin olumlu etkisi gözlenmiştir. Sadece B1 vitamini kaynaklarının atak sıklığı ile istatistiksel olarak anlamlı bir ilişkisi olduğu saptanmıştır. Omega3 ve D vitamini takviyesi alım durumlarının atakların sıklı̆̆ı ve çeşidine etkisi gözlenmemiştir.

Sonuç: Bütün hastalıklarda olduğu gibi MS oluşumunda, atakların sıklığında ve çeşidinde yeterli ve dengeli beslenmenin ne kadar önemli olduğu bu çalışmada da görülmüştür. Sadece yeterli ve dengeli beslenmenin değil sağlıklı bağırsak mikrobiyota oluşumunu etkileyen

\footnotetext{
Özgün Araştırma Makalesi (Original Research Article)

Geliş / Received: 11.06.2018 \& Kabul / Accepted: 30.07.2018

* Öğr. Gör., İstanbul Gelişim Üniversitesi, Sağlık Bilimleri Yüksekokulu, İstanbul, Türkiye, E-posta: ahozkarabulut@gelisim.edu.tr ORCID ID https://orcid.org/o000-0002-4977-6753

** Arş. Gör., İstanbul Gelişim Üniversitesi, Sağlık Bilimleri Yüksekokulu, İstanbul, Türkiye, Eposta: hnonur@gelisim.edu.tr ORCID ID https://orcid.org/0000-0001-6445-0519

**** Diyetisyen, İstanbul Gelişim Üniversitesi, Sağlık Bilimleri Yüksekokulu, İstanbul, Türkiye, E-posta: ipekyasar.92@gmail.com, ORCID ID https://orcid.org/o0oo-0002-3054-2340
} 
probiyotik, prebiyotik ürünlerin, posanın, fonksiyonel besinlerin de antioksidan özelliklerinden dolayı mutlaka tüketilmesi gerekmektedir.

Anahtar Sözcükler: Multiple skleroz, probiyotik, prebiyotik.

\title{
Comparison of Nutrition Habits Before and After Multiple Sklerosis (MS) Disease, Investigation of the Effects of Quality and Balanced Nutrition on the MS Attacks
}

\begin{abstract}
Aim: In this study, we compared the nutritional habits of before and after MS and the effect of adequate and balanced nutrition on MS attacks was investigated.

Method: This study was conducted in accordance with the data collection form on the internet without the place. It was formed with the participation of 98 patients diagnosed with MS and the mean age was $34.08 \pm 7.93$ years. Nutritional status of before and after MS, general information, anthropometric measurements, educational level, working status and physical activity levels of the participants were evaluated. SPSS program was used to evaluate the data.

Findings: According to the results, positive effects of consumption of probiotic, prebiotic, fiber, vitamin B1 and selenium source products were observed in decreasing attack frequency. It was found that only vitamin B1 sources had a statistically significant relationship with the frequency of attacks. The effects of supplementation of Omega-3 and vitamin D on the frequency and type of attacks were not observed.
\end{abstract}

Conclusion: In this study, the importance of adequate and balanced nutrition on MS formation, frequency and variety of attacks has seen, as in all diseases. Not just adequate and balanced nutrition, but also probiotic, prebiotic products, fiber and functional foods that affect the formation of healthy intestinal microbiota should be consumed due to their antioxidant properties.

Keywords: Mutiple sklerosis, probiotic, prebiotic.

\section{Giriş}

Multiple skleroz (MS), sıklıkla genç erişkinleri etkileyen, santral sinir sisteminin (SSS) yaygin demiyelinizan lezyonları ile karakterize, kronik bir hastalıktır. Nedeni tam olarak bilinmemekle birlikte etyopatogenezinde hem genetik, hem de çevresel faktörlerin tetiklediği, otoimmün mekanizmaların rol oynadığ düşünülmektediiri-3. Yaşam süresine etkisi olmamasına rağmen uzun yllar içinde gelişen yeti yitimi 
sonucunda giderek artan özürlülük durumu hastanın ve ailesinin yaşam kalitesini sinırlamaktadır 4,5 .

Otoimmün hastalıklar özellikle de MS kadınları erkeklerden daha sık etkiler. İnsidans ve prevelansın incelendiği 30 çalışmanın özetine göre kadın/erkek oranı 1,77/1,00 olarak bulunmuştır ${ }^{6}$. Kuzey ve güney yarımkürelerde enlem $65^{\circ}$ ye kadar arttıkça, hastalığın görülme sıklığı da artmaktadır. $65^{\circ}$ üzerindeki enlemlerde ise bu oranların düştüğü gözlenmiştir. Görülme sıklığı açısından dünyada yüksek, orta ve düşük görülme bölgeleri tanımlanmıştır. Yüksek sıklıkla görülen yerler Kuzey Avrupa, İsrail, Kanada, Kuzey Amerika, Yeni Zelanda, Güneydoğu Avustralya olup prevelans 30/10000o üzerindedir. Orta grupta Avustralya, Güney Amerika, Güneybatı Norveç, Kuzey İskandinavya, Ukrayna, Güney Afrika olup prevelans 15-25/100ooo'dir. Düşük sıklıkta görülen yerler ise Asya, Afrika, Güney Amerika'nın kuzeyi olup prevelansı 5/100ooo altındadır. Aynı coğrafyada yaşayan farklı ırk ve etnik gruplarda belirgin prevalans farklılıkları bildirilmiştir5. MS prevalansının düşük olduğu ülkelerden, MS prevalansının yüksek olduğu ülkelere göç eden topluluklarda yapılan epidemiyolojik çalışmalarda yaş faktörünün oldukça önemli olduğu görünmektedir. 14-15 yaşından önce göç edenlerde prevelans, göç edilen ülkeye uymakta, sonra göç edenlerde ise terk ettikleri ülkeye uyduğu görülmektedir ${ }^{7,8}$.

Normal miyelinize aksonlar ile demiyelinize olmuş aksonların fizyolojik özelliklerinin karşılaştırılması MS’in belirti ve klinik özelliklerinin temellerini kavramada yardımcı olur. Kompakt miyelin oligodendrositleri lipitten zengin plazma membranıdır ve akson boyunca ilerleyen elektrik uyarıları için izolasyon görevi yapar5.

MS, Santral Sinir Sistemi (SSS)'indeki lezyonların zamansal ve bölgesel dağılımı ile karakterizedir. Nörolojik bulgular demiyelinizan lezyonların lokalizasyonuna ve genişliğine göre çeşitlilik gösterir ${ }^{3}$. Beyinde motor lifler ile ilgili bir alanda demiyelinizasyon var ise kuvvetsizlik; koordinasyonla ilgili bir alan etkilenmiş ise koordinasyon bozukluğu; duyu ile ilgili alan etkilenmiş ise uyuşma, yanma karıncalanma hissi gibi semptomlar izlenmektedir. Hastaların yarısında ilk belirti bir veya daha fazla ekstremitede güçsüzlük veya uyuşukluk ya da ikisinin birlikteliğidir ${ }^{6}$. Hastalığın tanısında Manyetik Rezonans Görüntüleme (MRG), beyin omurilik sıvısı (BOS) ve bazı nörofizyolojik testler (uyandırılmış potansiyeller, beyin sapı refleksleri) kullanılmaktadır ${ }^{3,9}$. 
MS atakları, hedef organ dışında oluşan hücresel aktivasyonuyla tetiklenmektedir. Periferde aktive olan hücreler SSS içinde reaktive olurlar. SSS içindeki immün cevaplar daha önce filtrelenmemiş olan aktive periferik hücreler ve SSS in kronik olarak aktive olmuş kendi hücreleri tarafından da artırılmaktadır. Yapılan çalışmalarda MS hastalığının başlangıcının SSSne yönelmiş otoreaktif $\mathrm{T}$ hücrelerinin periferde aktive olmasından kaynaklandığını düşündürmektedir. SSS içinde oluşan aktif immün cevapların, SSS miyelini, oligodentrositler ve nöral yapıların bütünlüğü üzerine etkisi vardır. MS’in T hücre aracılı otoimmün bir hastalık olduğu konusunda görüş birliği olmasına rağmen, otoreaktif $\mathrm{T}$ hücrelerinin nasıl aktive olduğu ve inflamasyonun zaman içinde neden tekrar ettiği hala bilinmeyen bir konudur ${ }^{6,10}$.

Akım, demiyelinizasyon ile akson üzerindeki yalıtım etkilendiği için bozulur. Kısa segmentte olan demiyelinizasyon, genelde kritik değilken daha uzun segmentin demiyelinizasyonu ile akım durur ve ileti bloğu olur. Büyük plak bölgesindeki iletinin bloklanması ile kalıcı nörolojik bulgular olurken, iletim için güvenlik eşiğinin altına düşme ile bir işlevin geçici olarak kötüleşmesi gözlenir. Yapısal değişikliklerin yanında sinir iletisi, hücreler ve akson için toksik olabilecek plakta ya da plak çevresindeki bağışıklık hücrelerinden salınan sitokinler, kemokinleri, adezyon molekülleri gibi çözünebilen faktörler ve ödem tarafindan bozularak aksonda işlevsel bozukluklar oluşabilirir112.

Klasik nörodejeneratif hastalıkların tersine tüm MS lezyonlarına hastalık tip ve dönemine bakılmaksızın inflamasyon eşlik eder; ancak hastalığın dönemine bağlı olarak inflamatuvar yanıtın nitelik ve niceliği değişisir,13-16.

MS ile ilişkisi tartışılan, henüz net olarak ortaya koyulamayan çevresel faktörler; cerrahi operasyon, anestezi, evcil hayvan besleme, diş dolgusunda kullanılan amalgam, organik çözücüler, endüstrileşme, travma, aşılar, nütrisyonel alışkanlıklar, güneş ışınlarına maruziyet ve D vitaminidir ${ }^{7,17}$.

Beslenme alışkanlıkları immün fonksiyonlar üstünde etkilidir. Sebze ve meyveden, omega 3 ten zengin beslenme, balık tüketiminin arttırılması; total ve hayvansal yağların tüketiminin azalması bu hastalıkta olumludur fakat kesin kanıtlar mevcut değildir ${ }^{16}$. Yapılan çalışmalarda MS insidansı ile hayvansal kaynaklı doymuş yağ tüketimi arasında ilişki olduğu iddia edilse de vaka kontrol çalışmalarında aynı iddia ispatlanamamıştır. Aynı şekilde şeker, alkol, füme et ürünleri, kahve, çay gıdalar MS ile ilişkilendirilmiş 
olup bu ilişki doğrulanamamıştır. Düşük hayvansal yağlı, çoklu doymamış yă̆ asitlerinden zengin Swank diyeti, Kousmine diyeti en bilinen diyetlerdendir ${ }^{18}$.

Diyetsel müdahalelerin Multipl Skleroz yönetiminde oynayabileceği rol, hastalar ve araştırmacılar arasında büyük bir ilgi uyandırmaktadır, ancak bunu değerlendiren veriler sınırlıdır. Çok az yağlı, bitki bazlı diyet müdahalesinin MS ile ilişkili progresyon ve beyin görüntüleme ve MS ile ilişkili semptomlarla ölçülen hastalık aktivitesi üzerindeki muhtemel etkileri, randomize kontrollü bir çalışmada değerlendirilmemiştir ${ }^{19}$.

Eksikliğinde hematolojik ve nörolojik belirtilerin görüldüğü $\mathrm{B}_{12}$ vitamininin MS ile ilişkisi konusunda da çeşitli çalışmalar yapılmıştır. $\mathrm{Bu}$ çalışmalarda $\mathrm{B}_{12}$ vitamin düzeylerinin azalmasının MS’e yatkınlığı artırabileceği ve hastalığın aktivitesini değiştirebileceği belirtilmektedir ${ }^{7,20}$.

Bu çalışmada Multiple Skleroz (MS) hastalarında, MS hastalığı öncesi ve MS hastalığı sonrası beslenme alışkanlıklarının karşılaştırılması, yeterli ve dengeli beslenmenin MS ataklarına olan etkisinin irdelenmesi başlığı altında gerçekleştirilen çalışmanın, beslenme düzeninin değişmesi ile D vitamini, selenyum, probiyotik gibi gıda bileşenlerinin değişik düzeylerde alınmasının MS e etkisinin belirlenmesi amaçlanmıştır.

\section{Gereç ve Yöntem}

$\mathrm{Bu}$ çalışma; oluşturulan veri toplama formu doğrultusunda (genel bilgiler, boy, ağırlık, MS öncesi - MS sonrası besinlerin tüketim sıklıkları, atak çeşitleri ve sıklı̆̆ı) ulaşılan, MS tanısı almış çalışmaya katılmayı kabul eden ve internet üzerinden veri toplama

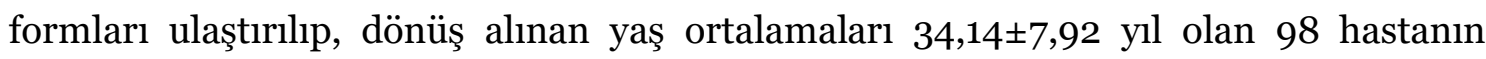
katılımı ile oluşmuştur. Hastaların beyanları ile tüketimleri sorgulanan besinler; probiyotikler için kefir, yoğurt, peynir, turşu, ayran, keçi sütü; prebiyotikler için kurubaklagiller, soğan, sarımsak, pırasa, bezelye, kuşkonmaz, çavdar, muz, enginar; posa için sebze-meyve, kurubaklagil, yağlı tohumlar, keten tohumu, tam tahıllılar, bulgur; selenyum için deniz ürünü, kırmızı et, ayçekirdeği çekirdeği, kuruyemiş, yumurta, kümes hayvanları; B1 vitamini için ceviz, yumurta sarısı, ayçiçeği çekirdeği, esmer pirinç, yer fıstığı, kuzu karaciğeri; ayrıca et, yumurta ve balıktır. D vitamin ve omega 3 için suplement kullanımı sorgulanmıştır. 
Boy uzunluğu ve vücut ağırlığına dayalı bir indeks olan Beden Kütle İndeksi (BKİ), toplum düzeyinde şişmanlığı ve şişmanlık riskini tanımlamaktadır. BKİ’nin hesaplanabilmesi için vücut ağırlığı ve boy uzunluğu tekniğine göre ölçülür. Vücut ağırlığının (kg cinsinden) boy uzunluğunun (metre cinsinden) karesine bölünmesiyle hesaplanır [BKİ: Vücut ağırlığı (kg)/boy uzunluğu $(\mathrm{m})^{2}$ ]. Yetişkinlerde BKİ'nin değerlendirilmesi aşağıda verilmiştir (Tablo 1).

Tablo 1: BKİ sınıflandırılması

\begin{tabular}{|c|c|c|}
\hline \multirow{2}{*}{ SINIFLANDIRMA } & \multicolumn{2}{|l|}{ BKİ $\left(\mathbf{k g} / \mathbf{m}^{2}\right)$} \\
\hline & Temel Kesişim Noktaları & Temel Kesişim Noktaları \\
\hline ZAYIF & $<18.50$ & $<18.50$ \\
\hline Ăğır & $<16.00$ & $<16.00$ \\
\hline Orta & $16.00-16.99$ & $16.0-16.99$ \\
\hline Hafif & $17.00-18.49$ & $17.0-18.49$ \\
\hline \multirow{2}{*}{ NORMAL } & \multirow{2}{*}{$18.50-24.99$} & $18.5^{-22.99}$ \\
\hline & & $23.00-24.99$ \\
\hline HAFİF ŞİŞMAN (KİLOLU) & $\geq 25.00$ & $\geq 25.00$ \\
\hline \multirow{2}{*}{ Şişmanlık öncesi } & \multirow{2}{*}{$25.00-29.99$} & $25.00-27.49$ \\
\hline & & $27.50-29.99$ \\
\hline ŞİŞMAN & $\geq 30.00$ & $\geq 30.00$ \\
\hline \multirow{2}{*}{ I. Derece Şişman } & \multirow{2}{*}{$30.00-34.99$} & $30.00-32.49$ \\
\hline & & $32.50-34.99$ \\
\hline \multirow{2}{*}{ II. Derece Şişman } & \multirow[t]{2}{*}{$35.00-39.99$} & $35.00-37.49$ \\
\hline & & $37.50-39.99$ \\
\hline III. Derece Şişman & $\geq 40.00$ & $\geq 40.00$ \\
\hline
\end{tabular}

* T.C. Sağlık Bakanlığı, Türkiye Halk Sağlı̆̆ı Kurumu. Türkiye’ye Özgü Beslenme Rehberi 2015, Ankara, 2016.

Çalışmada kullanılan kategorik değişkenlerin karşılaştırmalarında Pearson Chi-Square testleri kullanılmıştır. İstatistik analizleri sonucunda elde edilen yanılma olasılı̆̆ı (p) değeri 0.05'ten küçük ise sonuç istatistiksel olarak önemli kabul edilmiş ve bütün istatistiksel hesaplamalarda SPSS.17 programı kullanılmıştır.

İstanbul Gelişim Üniversitesi etik kurulunun 27.07.2015 tarih ve 2015-13 sayll toplantısının 2 numaralı kararı ile etik kurul onayı alınmıştır. 


\section{Bulgular}

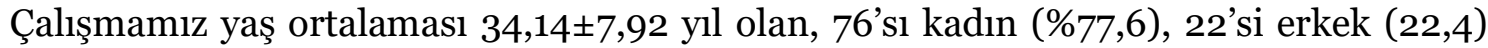
toplam 98 hasta ile yürütülmüştür. MS bulunma sıklığı kadınlarda daha fazla görülmektedir. Fakat bu fark istatistiksel olarak anlamı değildir. (p>0.05). Tablo 2'de çalışmaya katılan katılımcıların sosyodemografik özellikleri belirtilmiştir.

Tablo 2: Araştırma grubunun sosyodemografik özellikleri

\begin{tabular}{|l|l|l|l|}
\hline & $\mathbf{n}$ & $\mathbf{\%}$ & $\mathbf{p}$ \\
\hline Cinsiyet & 77 & 77,8 & ,,20 \\
Kadın & 22 & 22,2 & \\
Erkek & 32 & 32,7 & \\
\hline Medeni Durum & 60 & 61,2 & \\
Evli & 6 & 6,1 & \\
Bekar & & & \\
Dul & 26 & 26,5 & \\
\hline Gelir Durumu & 56 & 57,1 & \\
Gelir < Gider & 16 & 16,4 & \\
Gelir = Gider & & & \\
Gelir > Gider & 2 & 2,0 & \\
\hline Eğitim Durumu & 2 & 2,0 & \\
Okur-yazar değil & 23 & 23,5 & \\
İlköğretim & 12 & 12,2 & \\
Ortaöğretim & 59 & 60,3 & \\
Önlisans & 61 & 62,2 & \\
Lisans ve Lisansüstü & 37 & 37,8 & \\
\hline Çalışma Durumu & & \\
Çalş̧yor & Çalş̧mıyor & &
\end{tabular}

Tablo 3'de fiziksel aktivite düzeyi ve BKİ sınıflarının atakların ortaya çıkış şekline etkisi karşlaştırılmıştır. Gruplar arasında istatiksel olarak anlamlı bir fark bulunmamıştır. (p>0.05) 
Tablo 3: BKİ sınıfı ile atak şekillerinin karşılaştırılması

\begin{tabular}{|c|c|c|c|c|c|c|}
\hline & \multicolumn{6}{|c|}{ Atakların ortaya çıkış şekli } \\
\hline & $\begin{array}{l}\text { Tekrarlayan } \\
\text { baş } \\
\text { dönmeleri }\end{array}$ & $\begin{array}{l}\text { Görme } \\
\text { kaybı ve } \\
\text { bulanık } \\
\text { görme }\end{array}$ & $\begin{array}{l}\text { Çift } \\
\text { görme, } \\
\text { peltek } \\
\text { konuşma }\end{array}$ & $\begin{array}{l}\text { Vücudun bir } \\
\text { yarısında } \\
\text { veya her iki } \\
\text { bacakta } \\
\text { uyuşma }\end{array}$ & $\begin{array}{l}\text { Boyun } \\
\text { hareketleri } \\
\text { ile ortaya } \\
\text { çlkan } \\
\text { elektriklenme } \\
\text { hissi }\end{array}$ & $\mathbf{P}$ \\
\hline BKI Sinif & & & & & & \\
\hline Zayıf & 3 & 4 & 2 & 2 & 1 & \\
\hline Normal kilolu & 17 & 11 & 3 & 12 & 1 & \\
\hline Fazla kilolu & 11 & 11 & 1 & 6 & 1 & \\
\hline 1.derece obez & 4 & - & - & 3 & - & 0,789 \\
\hline 2.derece obez & 2 & 1 & - & 2 & - & \\
\hline
\end{tabular}

Prebiyotik ve posa olarak değerlendirilen kurubaklagil MS sonrasinda $(\mathrm{p}=\mathrm{o}, \mathrm{036}$ ); selenyum kaynağı olarak değerlendirilen deniz ürünleri hem MS öncesi $(p=0,047)$ hem de MS sonrasinda $(\mathrm{p}=0,006)$ ve kümes hayvanları sadece MS sonrasinda $(\mathrm{p}=0,010)$; tiamin kaynağı olarak değerlendirilen yer fistığı hem MS öncesi ( $\mathrm{p}=0,000)$ hem de MS sonrasında $(p=0,014)$ ve kuzu karaciğeri sadece MS sonrasında $(p=0,007)$ tüketim sıklıkları karşılaştırıldığında istatistiksel olarak anlamlı bulunmuştur. Diğer incelenen besinlerin sıklıkları arasında anlamlı bir sonuç bulunamamıştır (Tablo 4).

Tablo 4: MS öncesi ve sonrasında tüketilen besinlerin atak sıklığına etkisi

\begin{tabular}{|l|l|l|l|l|l|l|l|}
\hline \multirow{2}{*}{$\begin{array}{l}\text { MS } \\
\text { Öncesi/Sonrası } \\
\text { Besin Tüketim } \\
\text { Durumu }\end{array}$} & $\begin{array}{l}\text { Haftada } \\
\text { bir }\end{array}$ & $\begin{array}{l}\text { Ayda } \\
\text { bir }\end{array}$ & $\begin{array}{l}\text { Üç } \\
\text { ayda } \\
\text { bir }\end{array}$ & $\begin{array}{l}\text { Altı } \\
\text { ayda } \\
\text { bir }\end{array}$ & $\begin{array}{l}\text { Ylda } \\
\text { bir }\end{array}$ & $\begin{array}{l}\text { Uzun zamandır } \\
\text { atak } \\
\text { geçirmiyorum }\end{array}$ & $\begin{array}{l}\text { P } \\
\text { değeri }\end{array}$ \\
\hline $\begin{array}{l}\text { MS sonrası } \\
\text { (kurubaklagil) }\end{array}$ & & & & & & & \\
Hiç & 1 & - & 1 & - & - & 2 & \\
Ayda bir & 2 & - & 2 & - & 4 & 10 & \\
Haftada bir & 1 & 1 & 5 & 3 & 9 & 32 & $0,036^{*}$ \\
Haftada 1-3 & - & - & 1 & 7 & 5 & 6 & \\
Haftada 4-6 & - & - & 1 & - & 2 & 2 & \\
Hergün & - & - & - & 1 & - & - & \\
\hline
\end{tabular}




\begin{tabular}{|c|c|c|c|c|c|c|c|}
\hline \multicolumn{8}{|c|}{$\begin{array}{l}\text { MS öncesi (deniz } \\
\text { ürünü) }\end{array}$} \\
\hline Hiç & 3 & - & 2 & 3 & 4 & 5 & \\
\hline Ayda bir & - & 1 & 8 & 2 & 11 & 29 & \\
\hline Haftada 1 & 1 & - & - & 4 & 5 & 13 & $0,047^{*}$ \\
\hline Haftada 1-3 & - & - & - & 1 & - & 5 & \\
\hline Haftada 4-6 & - & - & - & 1 & - & - & \\
\hline Hergün & - & - & - & - & - & - & \\
\hline \multicolumn{8}{|c|}{$\begin{array}{l}\text { MS sonrası (deniz } \\
\text { ürünü) }\end{array}$} \\
\hline Hiç & 3 & - & 2 & 1 & - & 5 & \\
\hline Ayda bir & - & 1 & 7 & - & 11 & 18 & \\
\hline Haftada bir & 1 & - & 1 & 7 & 8 & 21 & \\
\hline Haftada 1-3 & - & - & - & 3 & 1 & 7 & $0,006^{*}$ \\
\hline Haftada 4-6 & - & - & - & - & - & 1 & \\
\hline Hergün & - & - & - & - & - & - & \\
\hline \multicolumn{8}{|l|}{ MS sonrası } \\
\hline Hiç & 2 & - & 1 & - & 1 & 4 & \\
\hline Ayda bir & - & - & 6 & 1 & 2 & 17 & \\
\hline Haftada bir & 2 & 1 & - & 4 & 10 & 18 & \\
\hline Haftada 1-3 & - & - & 2 & 4 & 7 & 11 & $0,010^{*}$ \\
\hline Haftada 4-6 & - & - & - & 2 & - & 2 & \\
\hline Hergün & - & - & 1 & - & - & - & \\
\hline \multicolumn{8}{|c|}{$\begin{array}{l}\text { MS öncesi (yer } \\
\text { fistığı) }\end{array}$} \\
\hline Hiç & 1 & - & 4 & 7 & 8 & 26 & \\
\hline Ayda bir & 3 & - & 4 & 4 & 7 & 13 & \\
\hline Haftada 1 & - & - & 2 & - & 3 & 12 & \\
\hline Haftada 1-3 & - & 1 & - & - & 1 & - & \\
\hline Haftada 4-6 & - & - & - & - & - & - & $0,000^{*}$ \\
\hline Hergün & - & - & - & - & 1 & 1 & \\
\hline \multicolumn{8}{|c|}{$\begin{array}{l}\text { MS sonrası (yer } \\
\text { fistığı) }\end{array}$} \\
\hline Hiç & 2 & - & 6 & 8 & 6 & 28 & \\
\hline Ayda bir & 2 & - & 4 & 2 & 9 & 11 & \\
\hline Haftada bir & - & - & - & 1 & 3 & 10 & \\
\hline Haftada 1-3 & - & 1 & - & - & 1 & 2 & \\
\hline Haftada 4-6 & - & - & - & - & - & - & $0,014^{*}$ \\
\hline Hergün & - & - & - & - & 1 & 1 & \\
\hline
\end{tabular}




\begin{tabular}{|l|l|l|l|l|l|l|l|}
\hline $\begin{array}{l}\text { MS sonrası (kuzu } \\
\text { karaciğer) }\end{array}$ & & & & & & & \\
Hiç & 1 & 1 & 8 & 8 & 16 & 37 & \\
Ayda bir & 2 & - & 1 & 3 & 4 & 12 & \\
Haftada 1 & - & - & - & - & - & 3 & 0,007 \\
Haftada 1-3 & 1 & - & - & - & - & - & \\
Haftada 4-6 & - & - & - & - & - & - & \\
Hergün & - & - & 1 & - & - & - & \\
\hline
\end{tabular}

MS öncesi ve sonrasında besinlerin atakları ortaya çıkarış şekline göre etkisi incelendiğinde MS öncesi balık ( $\mathrm{p}=0,003)$, deniz ürünü ( $\mathrm{p}=0,003)$, kırmızı et $(\mathrm{p}=0,024)$, yer fistığı $(\mathrm{p}=0,006)$, kuzu ciğeri $(\mathrm{p}=0,006)$; MS sonrası ise peynir ( $\mathrm{p}=0,033)$ ile anlamlı ilişkili olduğu bulunmuştur (Tablo 5).

Tablo 5: MS öncesi ve sonrasında tüketilen besinlerin atakların ortaya çıkış şekline etkisi

\begin{tabular}{|c|c|c|c|c|c|c|}
\hline & $\begin{array}{l}\text { Tekrarlayan } \\
\text { baş } \\
\text { dönmesi ve } \\
\text { dengesizlik }\end{array}$ & $\begin{array}{l}\text { Görme } \\
\text { kaybı } \\
\text { veya } \\
\text { bulanık } \\
\text { görme }\end{array}$ & $\begin{array}{l}\text { Çift } \\
\text { görme, } \\
\text { peltek } \\
\text { konuşma }\end{array}$ & $\begin{array}{l}\text { Vücudun bir } \\
\text { yarısında veya } \\
\text { her iki bacakta } \\
\text { uyuşma }\end{array}$ & $\begin{array}{l}\text { Boyun } \\
\text { hareketleri ile } \\
\text { ortaya çıan } \\
\text { elektriklenme } \\
\text { hissi }\end{array}$ & $\mathbf{P}$ \\
\hline \multicolumn{7}{|l|}{$\begin{array}{l}\text { MS öncesi } \\
\text { (balık) }\end{array}$} \\
\hline Hiç & 9 & 5 & 1 & 1 & - & \\
\hline Ayda bir & 17 & 14 & 2 & 16 & 1 & \\
\hline Haftada 1 & 9 & 8 & 2 & 7 & - & \\
\hline Haftada 1-3 & 2 & - & 1 & - & 2 & $0,003^{*}$ \\
\hline Haftada 4-6 & - & - & - & 1 & - & \\
\hline Hergün & - & - & - & - & - & \\
\hline \multicolumn{7}{|l|}{$\begin{array}{l}\text { MS öncesi } \\
\text { (deniz } \\
\text { ürünü) }\end{array}$} \\
\hline Hiç & 9 & 5 & 1 & 2 & - & \\
\hline Ayda bir & 16 & 12 & 3 & 19 & 1 & \\
\hline Haftada 1 & 9 & 10 & 1 & 3 & - & \\
\hline Haftada 1-3 & 3 & - & 1 & - & 2 & $0,003^{*}$ \\
\hline Haftada 4-6 & - & - & - & 1 & - & \\
\hline Hergün & - & - & - & - & - & \\
\hline
\end{tabular}




\begin{tabular}{|c|c|c|c|c|c|c|}
\hline \multicolumn{6}{|l|}{ MS öncesi } & \\
\hline Hiç & 3 & 2 & 2 & - & - & \\
\hline Ayda bir & 12 & 7 & 1 & 7 & - & \\
\hline Haftada 1 & 15 & 8 & 3 & 9 & 2 & \\
\hline Haftada 1-3 & 4 & 7 & - & 4 & - & $0,024^{*}$ \\
\hline Haftada 4-6 & 3 & 2 & - & 5 & - & \\
\hline Hergün & - & 1 & - & - & 1 & \\
\hline \multicolumn{7}{|l|}{$\begin{array}{l}\text { MS öncesi } \\
\text { (yer fistığı) }\end{array}$} \\
\hline Hiç & 16 & 11 & 2 & 17 & - & \\
\hline Ayda bir & 14 & 9 & 2 & 6 & - & \\
\hline Haftada 1 & 5 & 7 & 1 & 1 & 3 & \\
\hline Haftada 1-3 & 2 & - & - & - & - & $0,006^{*}$ \\
\hline Haftada 4-6 & - & - & - & - & - & \\
\hline Hergün & - & - & 1 & 1 & - & \\
\hline \multicolumn{7}{|l|}{ MS öncesi } \\
\hline karaciğer) & & & & & & \\
\hline Hiç & 22 & 11 & 2 & 17 & - & \\
\hline Ayda bir & 13 & 9 & 2 & 6 & - & \\
\hline Haftada 1 & 2 & 7 & 1 & 1 & 3 & $0,006^{*}$ \\
\hline Haftada 1-3 & - & - & - & - & - & \\
\hline Haftada 4-6 & - & - & - & - & - & \\
\hline Hergün & - & - & 1 & 1 & - & \\
\hline \multicolumn{7}{|l|}{$\begin{array}{l}\text { MS sonrasi } \\
\text { (peynir) }\end{array}$} \\
\hline Hiç & 3 & 2 & - & o & - & \\
\hline Ayda bir & - & 2 & - & o & - & \\
\hline Haftada 1 & 16 & 9 & 3 & 9 & 9 & \\
\hline Haftada 1-3 & 4 & 5 & - & 6 & 6 & $0,033^{*}$ \\
\hline Haftada 4-6 & 1 & 1 & - & 2 & 2 & \\
\hline Hergün & 13 & 8 & 3 & 8 & 8 & \\
\hline
\end{tabular}

\section{Tartışma}

Bu çalışmada, cinsiyet, BKI sınıfı, yaş, medeni durum, gelir durum, eğitim düzeyi, çalışma durumu ve MS ataklarına ve çeşidine etkisi olmadığı belirlenmiştir. 
MS sonrası prebiyotiklerden olan kurubaklagil tüketim durumunun atak sıklığına etkisi istatistiksel olarak anlaml $(\mathrm{p}=0,036)$ olduğu belirlenmiştir. Bunun nedeni kurubaklagillerin posa içermesidir. İnsanda bağışıklık dokularının \%80’i bağırsakta bulunmaktadır. Son zamanlarda yapılan çalışmalarda süper organizma adı verilen insan bağırsak mikrobiyotasının başta obezite, diyabet olmak üzere İmmün Bağırsak Hastalıkları, otizm, MS, Parkinson Hastalığı, Alzheimer Hastalığı gibi birçok hastalıkta önemli olduğu, bağırsak beyin ekseninin önemini ortaya koymuştur. Bağırsak mikrobiyotasının oluşumu kişinin beslenme türüne, yaşına, cinsiyetine, yaşadığı coğrafi konuma göre şekillenmektedir. Faydalı bakteri (probiyotik) sayısının ve bakteri çeşitliliğinin azalması bağırsak duvarı geçirgenliğini etkilemekte, bağırsak bütünlüğü bozulduğu zaman toksik maddeler karaciğere gitmekte, miktar fazla olduğunda temizlenmeyen toksik maddeler beyine giderek depresyon, otizm, MS gibi birçok hastalığa neden olmaktadır. Lifli besinlerin tüketilmesiyle oluşan kısa zincirli yă̆ asitleri özellikle bütirik asit ve probiyotikler bağırsak bütünlüğünü sağlamada çok önemli olmaktadır. Doymuş yağlar ve hayvansal proteinin aşırı tüketimi bağırsak duvarına zarar vermektedir. Bu durumun nedeni, yüksek yağlı diyet, gram negatif bakteri türlerinin oranının artmasına ve lipopolisakkarit gibi bakteri fragmanlarının artmasıdir ${ }^{19-22}$.

MS öncesi et tüketimi artması sonucu, MS çıktıktan sonra atak çeşidinin daha ağır seyrettiği çalışmamızda görülmüştür $(p=0,024)$. Bunun nedeni de etin içeriğindeki doymuş yağ asitleri ve kolesterolün fazla olması nedeniyle oluşan plaklar, beyine daha az oksijen gitmesine neden olabileceği düşünülmektedir. Swank diyetinin takibini konu alan bir çalışmada 144 multipl skleroz hastası 34 yıl boyunca az yağlı bir diyet almıştır. Belirlenen diyete ( $\leq 20$ g yağ/gün) bağlı nörolojik yetersizlik (minimum, orta, şiddetli) üç kategorinin her biri için, belirlenenden daha fazla yağ tüketenlere (>20 g yağ/gün) göre daha az kötüye gitme ve daha düşük ölüm oranları göstermiştir²3.

MS öncesi ve MS sonrası selenyum kaynağı olan tüm deniz ürünlerinin tüketiminin atak slklığına etkisi olumlu bulunmuştur ( $\mathrm{p}=0,047 ; \mathrm{p}=0,006)$. Bir başka selenyum kaynağı olan kümes hayvanları tüketiminin atak sıklığına etkisi anlamlı bulunmuştur ( $\mathrm{p}=0,01)$. MS öncesi tüketim haftada 1 iken, MS sonrası tüketim sıklığı haftada 1-3 şeklinde artmıştır. MS hastalarının plazma E vitamini, ubiquinol ve glutatyon peroksidaz düzeylerinin antioksidan aktiviteyi önemli ölçüde düşürdüğünü, MS 
hastalarının kanının oksidatif stresin önemli belirtileri gösterdiğini ve diyet vitamini olduğunu gösterdi. E ve selenyum hastalık ilerlemesini inhibe etmeye yardımcı olabilir ${ }^{24}$.

B1 vitamin kaynaklarından olan yer fistığı tüketim durumu atak sıklığı ile istatistiksel olarak anlamlı ilişkili bulunmuştur ( $\mathrm{p}=0,000)$. MS öncesi ve sonrası atak sıklığının anlamlı şekilde azaldığı ve atakların hafif semptomlarla geçtiği görülmüştür $(p=0,006)$. Araştırmacılar, güneş ışı̆̆ına maruziyet derecesinin deride D3 vitamini üretimini katalize etmesinin çevresel bir faktör olduğu ve D3 vitamininin hormonal formunun otoimmun hastalıkları inhibe eden immun sistem regülatörü olduğu hipotezini öne sürmüşlerdir. D vitamini eksikliğinin, MS’in remisyon ve ataklarını da belirlemede rolü olduğu düşünülmektedir. MS'de D vitaminin terapötik kullanımının temelini, D vitamininin aktif formunun hayvan çalışmalarında deneysel otoimmun ensefalomyelopatiden korumada efektif bulunması oluşturmaktadır ${ }^{18}$.

\section{Sonuç ve Öneriler}

Bütün hastalıklarda olduğu gibi MS oluşumunda, atakların sıklığında ve çeşidinde yeterli ve dengeli beslenmenin ne kadar önemli olduğu bu çalışmada da görülmüştür. Yiyecek grupları olarak ele aldığımızda:

Süt, yoğurt grubu: Probiyotik etkisinden dolayı tüketiminin yeterli ve dengeli olması istenmektedir. Süt yerine yoğurt, kefir, probiyotik yoğurtlar tercih edilmelidir. Peynir tercihi sindirimi kolay alerjen özelliği olmayan lor peyniri veya keçi peyniri tercih edilmelidir.

Et, balık, kuru baklagiller ve yağlı tohumlar: Kırmızı et B12 vitamini açısından önerilir ancak doymuş yağ ve kolesterol açısından diğer şarküteri ürünleri gibi mümkün olduğunca uzak durulmalıdır. Bunu sağlayabilmek için tereyağı, kuyrukyağı, iç yağı kontrollü tüketilmelidir. Hayvansal protein ihtiyacı omega-3 yönünden zengin balıklardan, selenyum açısından zengin organik tavuk ve hindi etinden sağlanmalıdır. Haftada 3-4 kez balık tüketilmeli, somon, uskumru, ton balığı gibi soğuk su balıkları tercih edilmelidir

Selenyum açısından deniz ürünleri de kullanılmalıdır. Günlük 1 mg'dan çok selenyum alımı toksik sayılır. Kandaki selenyum seviyelerine bakılarak serum düzeyi düşük ise selenyumdan zengin diyet verilmeli ve ek takviye alım sağlanmalı, yeterli ise 
selenyumdan zengin besinlerin tüketimine ağırlık verilmelidir, takviye selenyum almasina gerek yoktur.

Protein ihtiyacının bir kısmı bitkisel protein kaynakları olan kuru fasülye, nohut, mercimek, barbunya ve börülce gibi kurubaklagillerden karşılanmalıdır. $\mathrm{Bu}$ şekilde kurubaklagillerin hem prebiyotik etkilerinden hem de bağırsak florasının bütünlüğü açısından gerekli olan posadan yararlanmış oluruz.

Yumurta B12 ve D vitamini açısından önemlidir. Her gün 10 dakika kadar güneşlenilmesi de $\mathrm{D}$ vitamini aktivitesi açısından önerilmektedir. $\mathrm{D}$ vitamini düzeyinin MS'li olgularda $100 \mathrm{nmol} / \mathrm{L}$ (40 ng/ml) 'nin üzerinde olması gerektiği bildirilmektedir. $\mathrm{Bu}$ serum düzeyine ulaşılabilmesi için güneş ışığından yoksun bir kişinin günde 100 mcg D vitamini desteği alması gerekmektedir.

Her gün 1 avuç yağlı tohum (ceviz, çiğ badem, çiğ findık ve yer fıstığı) tüketilmesi önerilmektedir. $\mathrm{Bu}$ ürünlerin $\mathrm{E}$ vitamininden dolayı antioksidan etkileri MS'de çok önemlidir.

Sebze-meyve grubu: Her gün 3 porsiyon çiğ sebze tüketilmesi posa açısından önemlidir. Her gün 3 porsiyon çiğ meyve tüketilmeli ve tüketilen meyvelerin renk açısından çeşitlilik göstermesi farklı fonksiyonel içeriklerinden dolayı önemlidir. Genellikle mor renkli meyveler; ahududu, böğürtlen, üzüm, mürdüm eriği gibi meyvelerin tüketimi arttırılmalıdır.

\section{KAYNAKLAR}

1. Altındal A. Multipl Sklerozu immunopatogenezi ve patalojisi. Türkiye Klinikleri Nöroloji Özel Sayı. 2009;2(2):1-5.

2. Mirza M. Multip Sklerozun etyolojisi ve epidemiyolojisi. Erciyes Medical Journal. 2002;24(1):40-47.

3. Bayazit T. Multipl Skleroz'da Yorgunluğun ve Kognitif Fonksiyonların Manyetik Rezonans Bulgularıyla ve Tiroid Hormon ve Otoantikorlarıyla İlişkisi. [uzmanlık tezi]. Bolu, Türkiye: Abant İzzet Baysal Üniversitesi Tıp Fakültesi Nöroloji Anabilim Dalı, 2010. 
4. Confavreux C, Vukusic S, Adeleine P. Early clinical predictors and progression of irreversibl diability in multiple scleosis: an amnesic process. Brain. 2003;126:770-782. https://doi.org/10.1093/brain/awgo81.

5. Aydar G. Multipl Skleroz Hastalarında Huzursuz Bacak Sendromu Siklı̆̆ı. [uzmanlık tezi]. Tokat, Türkiye: Gaziosmanpaşa Üniversitesi Tıp Fakültesi Nöroloji Anabilim Dalı, 2010.

6. Şahin O. Multipl Sklerozlu Hastaların Bellek, Dikkat, Yürütücü İşlemler ve İnce Motor Hareket Yönünden Değerlendirilmesi. [uzmanlık tezi]. Kırıkkale, Türkiye: Kırıkkale Üniversitesi Tıp Fakültesi, 2013.

7. Tokgöz E. Multipl Sklerozda Serum Vitamin B12 Düzeyinin Klinik ve Laboratuvar Üzerine Etkisinin Araştırılması. [uzmanlık tezi]. Ankara: Türkiye: Gülhane Askeri Tıp Akademisi Nöroloji Anabilim Dalı, 2012.

8. International Multiple Sclerosis Genetics Consortium (IMSGC). Refining genetic associations in multiple sclerosis. Lancet Neurol. 2008;7(7):567-569. doi: 10.1016/S1474-4422(08)70122-4.

9. Karabudak R. Multipl Skleroz tanısında MR görüntülemenin değerlendirilmesi. Türkiye Klinikleri Nöroloji Özel Sayı. 2009;2(2):45-49.

10. İdiman E. Multipl Sklerozda beyin omurilik sıvısı. Türkiye Klinikleri Nöroloji Özel Sayı. 2009;2(2):50-55.

11. Dittel BN. CD4 T cells: Balancing the coming and going of autoimmunemediated inflammation in the CNS. Brain Behav Immun. 2008;22(4):421-430. doi: 10.1016/j.bbi.2007.11.010.

12. Çeçen İ. Multipl Skleroz Hastalarında Hijyen ve Yaşam Şartları. [uzmanlık tezi]. Afyonkarahisar, Türkiye: Afyon Kocatepe Üniversitesi Tıp Fakültesi Nöroloji Anabilim Dalı, 2013.

13. Hanneman KK, Cooper KD, Baron ED. Ultraviolet immunosuppression: mechanisms and consequences. Dermatol Clin. 2006;24:19-25. doi: 10.1016/j.det.2005.08.003.

14. Coles A. The curious incident of disability in multiple sclerosis trials. Lancet Neurol. 2006;5(11):899-900. doi: 10.1016/S1474-4422(06)70585-3. 
15. Kartı Üstün S. Multipl Sklerozlu Hastalarda Yorgunluk ile Mizaç Karakter Profili Arasındaki İlişkisi. [uzmanlık tezi]. Elazı̆̆, Türkiye: Fırat Üniversitesi Nöroloji Anabilim Dalı, 2010.

16. Türker FP. MS'de Beslenme. In: Katz DL, Friedman RSC, Lucan SC, eds. Çev. Kalkan İ, Akman M. Klinik Uygulamalarda Beslenme. 3. baskı. İstanbul: İstanbul Medikal Yayıncılık; 2018:329-330.

17. Pula JH, Reder AT. Multiple sclerosis. Part I: neuro-ophthalmic manifestations. Curr Opin Ophthalmol. 2009;20(6):467-75. doi: 10.1097/ICU.obo13e328331913b.

18. Demir A, Yıldız E. Multiple Skleroz ve Beslenme. Ortadoğu Medical Journal. 2015;7(3):144-148.

19. Yadav V, Marracci G, Kim E, et al. Low-fat,plant-based diet in Multiple Sclerosis: A randomized controlled trial. Multiple Sclerosis and Related Disorders. 2016;9:80-90. http://dx.doi.org/10.1016/j.msard.2016.07.001.

20. Van der Mei IA, Ponsonby AL, Dwyer T, et al. Past exposure to sun, skin phenotype, and risk of multiple sclerosis case-control study. BMJ. 2003;327(7410):316. doi: 10.1136/bmj.327.7410.316.

21. Nishijima S, Suda W, Oshima K, et al. The gut microbiome of healthy Japanese and its microbial and functional uniqueness. DNA Res. 2016;23(2):125-133. doi: 10.1093/dnares/dswoo2.

22. Conlon MA, Bird AR. The impact of diet and lifestyle on gut microbiota and human health. Nutrients. 2015;7(1):17-44. doi:10.3390/nu7010017.

23. Swank RL, Dugan BB. Effect of low saturated fat diet in early and late cases of multiple sclerosis. The Lancet. 1990;336(8706):37-39. https://doi.org/10.1016/0140-6736(90)91533-G.

24. Habek M, Hojsak I, Brinar VV. Nutrition in multiple sclerosis. Clinical Neurology and Neurosurgery. 2010;112:616-620. doi:10.1016/j.clineuro.2010.03.029. 